\title{
DESIGN OF A SUPERBIKE PADDOCK STAND USING CAD AND CAE TOOLS
}

\author{
H. Rashid ${ }^{1}$, A.H. Abdullah ${ }^{1}$, M.H. Mohd Noh ${ }^{1}$, A.H. Abdul Hamid ${ }^{1}$ \\ and N.M. Zainal Abidin ${ }^{1}$ \\ ${ }^{1}$ Faculty of Mechanical Engineering, Universiti Teknologi MARA Malaysia \\ 40450 Shah Alam, Selangor Darul Ehsan, Malaysia \\ Phone: +603 5543 6201, Fax: +603 5543 5160, \\ E-mail: helmi_rashid@salam.uitm.edu.my
}

\begin{abstract}
Two people are required to operate current superbike paddock stands in order to elevate the superbike. Lifting the superbike alone using the current design of paddock stand may be impractical and inconvenient for users. To overcome this limitation, a new design of a superbike paddock stand was conceived that could be operated by a single user. CAD and CAE tools using CATIA V5R18 software were utilised in designing this new stand. A 3D CAD model was developed and analysed through finite element analysis (FEA) and a prototype fabricated for verification testing of the design. The use of $\mathrm{CAD}$ and CAE tools saved much time in the design work and gave the researchers and designers freedom in producing their own design. However, the most important aspect of this design study was to design a superbike paddock stand that is more practical and convenient for operation by a single user.
\end{abstract}

Keywords: Superbike, paddock stand, computer aided design (CAD), finite element analysis (FEA).

\section{INTRODUCTION}

Superbikes with a dry weight of more than $100 \mathrm{~kg}$ rarely come with a double-stand, such as is commonly found on much lighter lower CC motorcycles. This double-stand functions as a temporary stand that places the motorcycle in a vertical standing position, which facilitates the ease of either periodic or ad-hoc maintenance work. The side-stand provided on superbikes, places the bike in a slanting position, which gives limited access for users to do maintenance work (Feyen et al., 2000). In addition, maintenance work on superbikes usually requires the bike to be lifted off the ground, allowing the superbike's tyres (front or rear tyre) to turn freely in a vertical position (Vanvalkenburgh, 2006; Siivonen, 2005). To facilitate this, a special type of jack is needed to safely lift the bike. The shared concept of the working principle of current designs of superbike paddock stands is to either lift the front or rear tyre depending on the necessary maintenance work. Current designs act as detachable stands used temporarily to stabilise the superbike and maintain its vertical aspect. Current designs of superbike paddock stands require two people to lift the superbike; one person needs to hold firmly the superbike in an upright standing position, whilst the other person lifts the bike by supporting its weight on its swing arm for the rear tyre, or on the front fork's bolt and nut for the front tyre. This puts the superbike in a stable and straight standing 
position, which gives users a much better working and reach area for performing maintenance work (Feyen et al., 2000).

\section{DESIGN METHODOLGY}

Figure 1 shows the design process involved in designing the superbike paddock stand (Ulrich and Eppinger, 2008). It starts by identifying the requirements of a stand that can be used by a single user. Ideas and concepts were generated before being selected using the Pugh decision matrix selection method (Thakker et al., 2009; Kuppuraju et al., 1985; Ulrich and Eppinger, 2008).

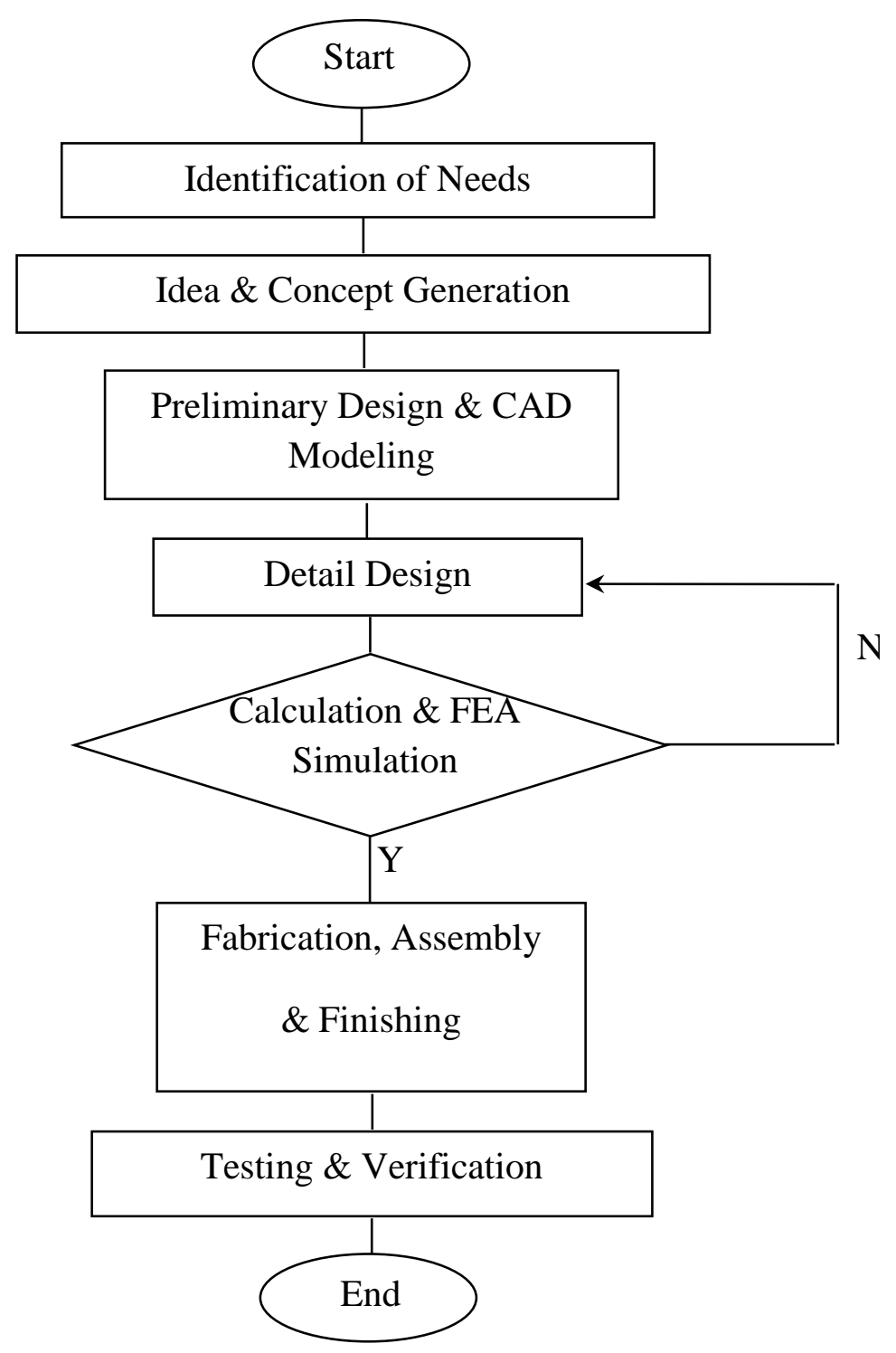

Figure 1. Design process involved in designing the superbike paddock stand

(Ulrich and Eppinger, 2008).

Detailed design of the superbike paddock stand was performed before it was modelled in a 3D CAD model using CAD software; CATIA V5R18 (Ulrich and Eppinger, 2008). Calculations and analysis through finite element analysis using CAE 
software; also CATIA V5R18, was then done on the 3D CAD model to analyse the maximum stresses acting on the new design (Karam and Kleismit, 2004; Mingzhou et al., 2002). To verify that the new design will not fail with the load acting upon it, a prototype was fabricated for testing with an actual superbike.

\section{DETAILED DESIGN AND MODELLING}

Three design concepts were generated combining many design factors including: functionality, assembly, maintainability, design simplicity, safety, quality, ergonomics and cost effectiveness. Using the Pugh decision matrix selection method (Thakker et al., 2009, Kuppuraju et al., 1985) as shown in Table 1, scores were determined for each design concept's criteria and the concept with the highest total average score was selected (Kuppuraju et al., 1985).

Table 1. Pugh decision matrix design selection.

\begin{tabular}{lccc}
\hline \multicolumn{1}{c}{ Criteria } & Design Concept 1 & $\begin{array}{c}\text { Score } \\
\text { Design Concept 2 }\end{array}$ & Design Concept 3 \\
\hline Functionality & 6 & 4 & 7 \\
Assembly & 5 & 5 & 8 \\
Maintainability & 7 & 5 & 8 \\
Design simplicity & 8 & 6 & 9 \\
Safety & 7 & 5 & 8 \\
Quality & 7 & 5 & 8 \\
Ergonomics & 7 & 6 & 8 \\
Cost Effectiveness & 8 & 6 & 7 \\
Total Average & 55 & 42 & 63 \\
\hline
\end{tabular}

Scoring Scale; Bad (1) - Excellent (10)

Figure 2 shows the current design of a superbike paddock stand and the design concept modelled using the CATIA V5R18 software for visualising the design concept (Karam and Kleismit, 2004) and the principle of how this new superbike paddock stand will function.
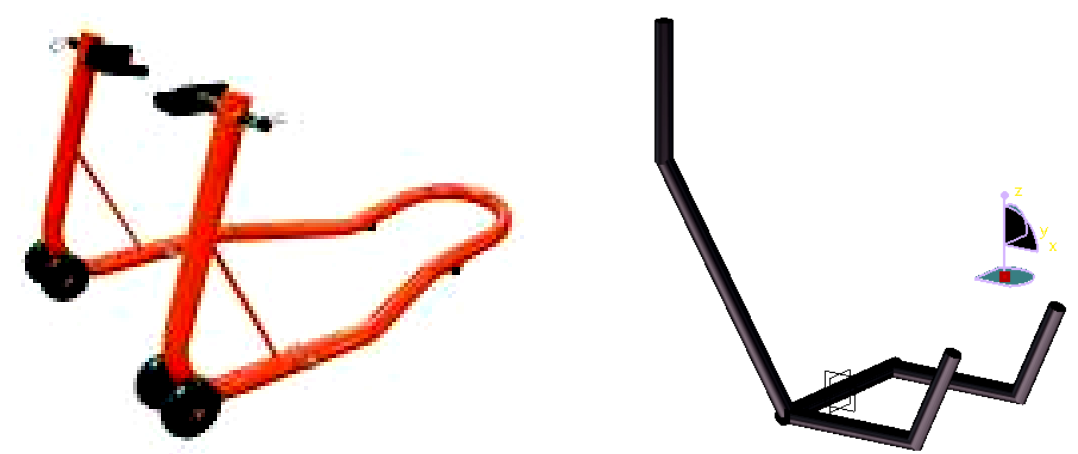

Figure 2. Current superbike paddock stand and the 3D conceptual design of CATIA V5R18 CAD model.

From the 3D CAD model of the design concept, a detailed design of the superbike paddock stand was developed. This detailed design includes all the elements 
to which the superbike paddock stand will adhere when fabricated (Ulrich and Eppinger, 2008). Figure 3 shows the detailed design of the superbike paddock stand modelled into a 3D CAD model using the CATIA V5R18 software.

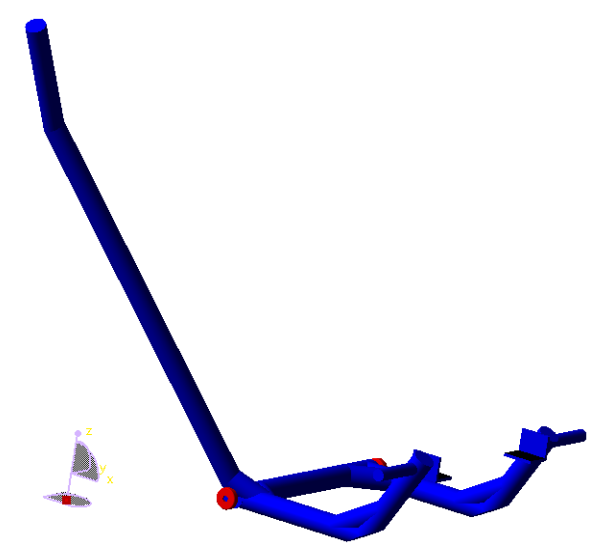

Figure 3. 3D CAD model of the superbike paddock stand; detailed design.

\section{FINITE ELEMENT MODEL AND ANALYSIS}

To analyse the maximum stresses acting on the designed stand, FEA was performed on the 3D CAD model. Using one of the CAE packages in CATIA V5R18 software, the finite element model was assigned with mild steel as the material (Ref. Figure 4) (Mingzhou et al., 2002; Riley et al., 1999). It was assigned as clamped at the lever surface, where the stand will rest when the bike is lifted, with $250 \mathrm{~kg}$ weight or $2.5 \mathrm{kN}$ of force acting on both ends of the support (Figure 5) (Bedford and Fowler, 2008).

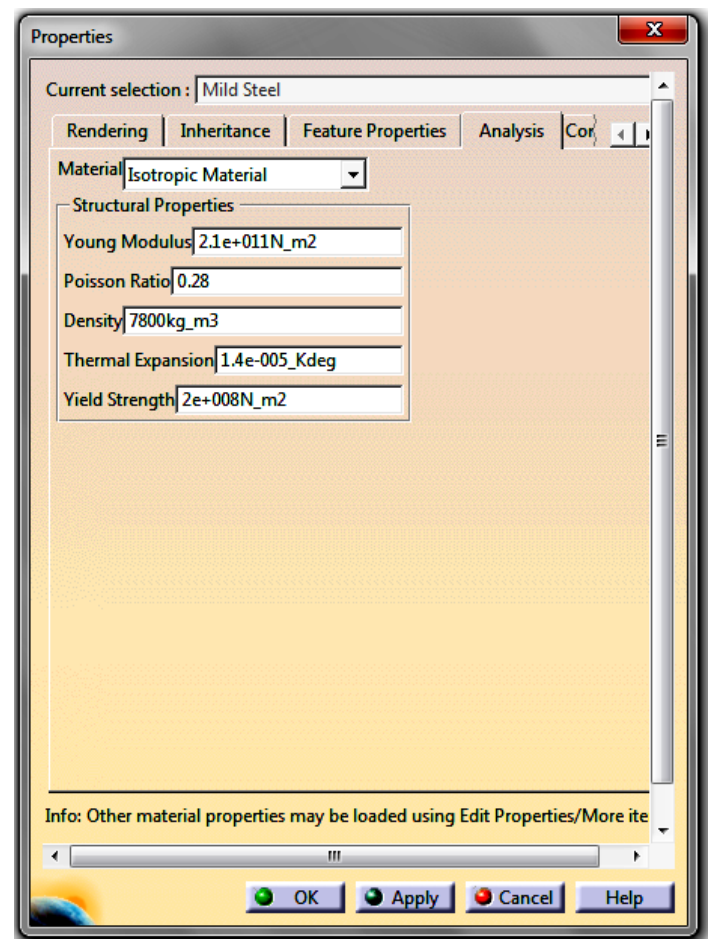

Figure 4. Material properties of finite element model. 


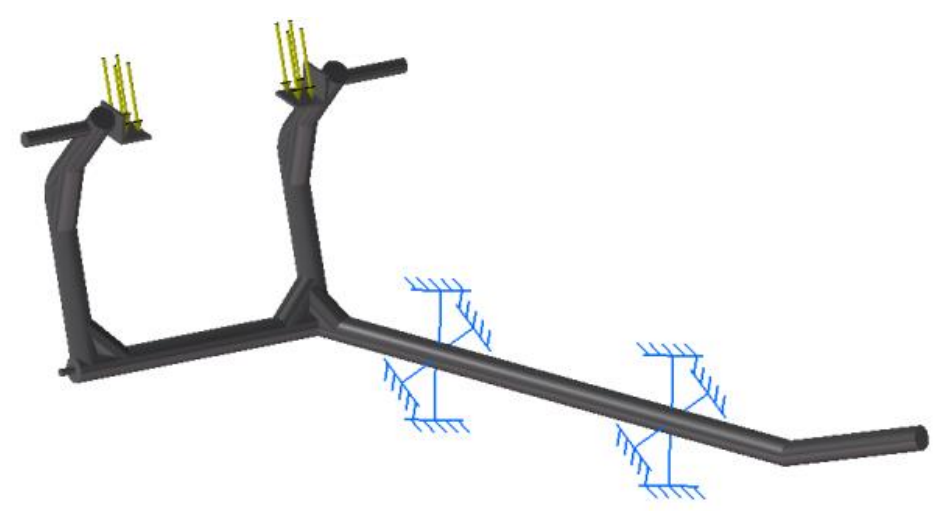

Figure 5. Boundary condition and acting load of finite element model.

\section{ANALYSIS RESULTS}

The analysis results consist of the deformation, von Mises Stress and translational displacement (Mingzhou et al., 2002) that occurs on the 3D CAD model of the designed stand, obtained through an FEA simulation using the CATIA V5R18 software. Figure 6 shows the deformation that the stand may undergo when load acts on it. However, the FEA revealed that hardly any deformation occurs. Figure 7 shows the von Mises stress (Mingzhou et al., 2002; Budynas and Nisbett, 2008) acting on the stand. The red area represents the maximum von Mises stress; $81.2 \mathrm{MPa}$, where the superbike paddock stand will be highly affected due to the load acting upon it. Figure 8 shows the translational displacement results when load is applied to the stand; the red area represents the maximum translational displacement of a $1.38 \mathrm{~mm}$.

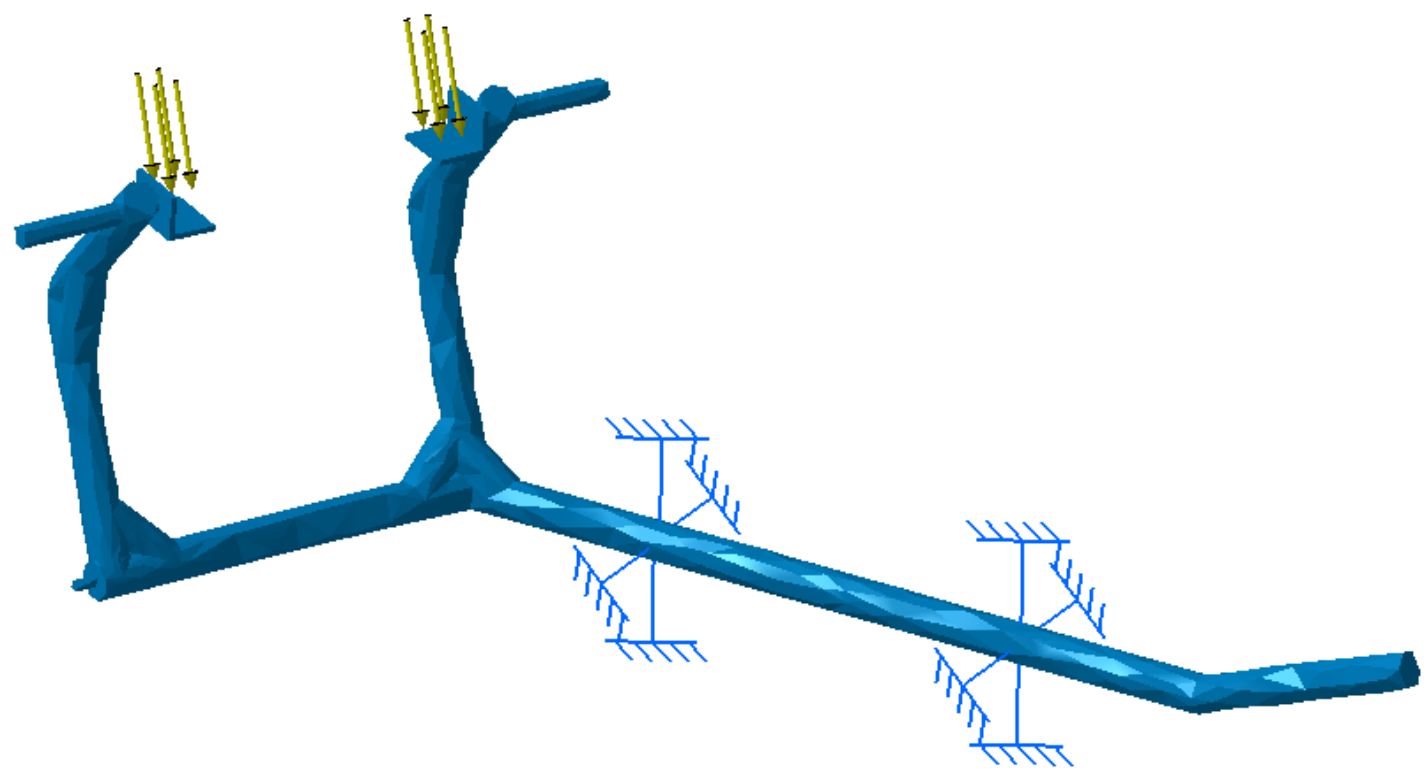

Figure 6. Deformation of the superbike paddock stand. 


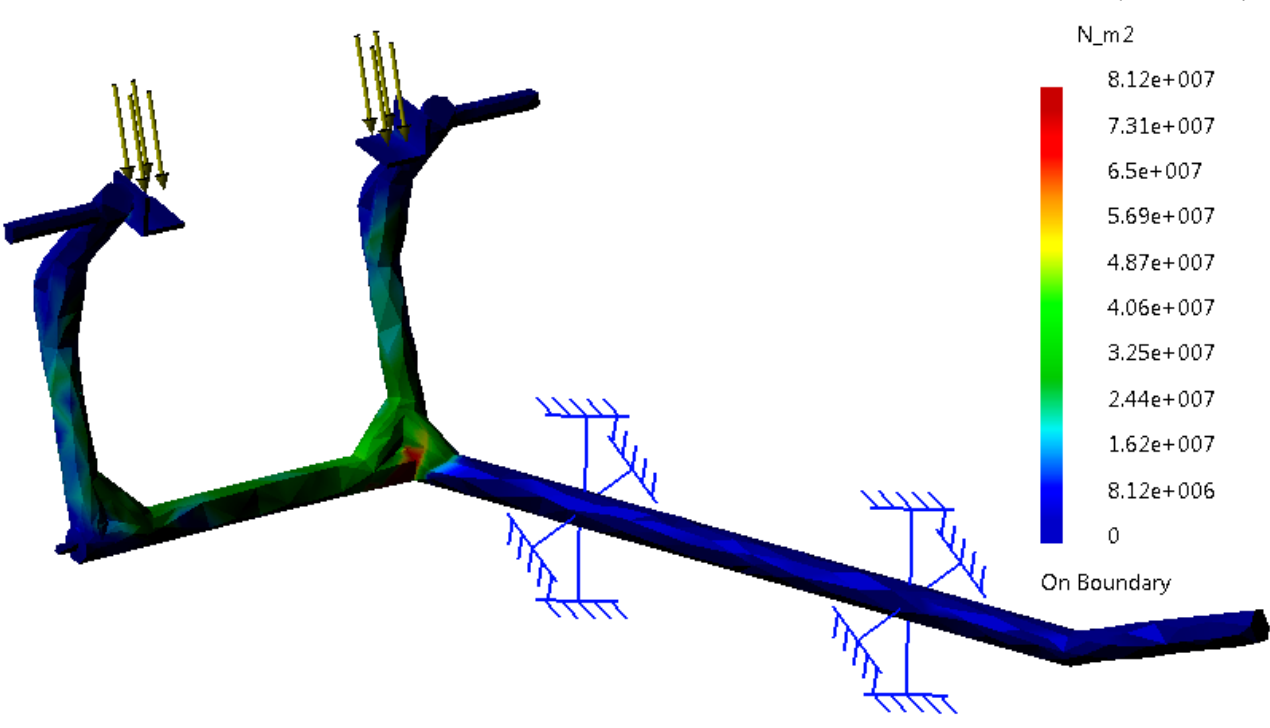

Figure 7. von Mises stress acting on the superbike paddock stand.

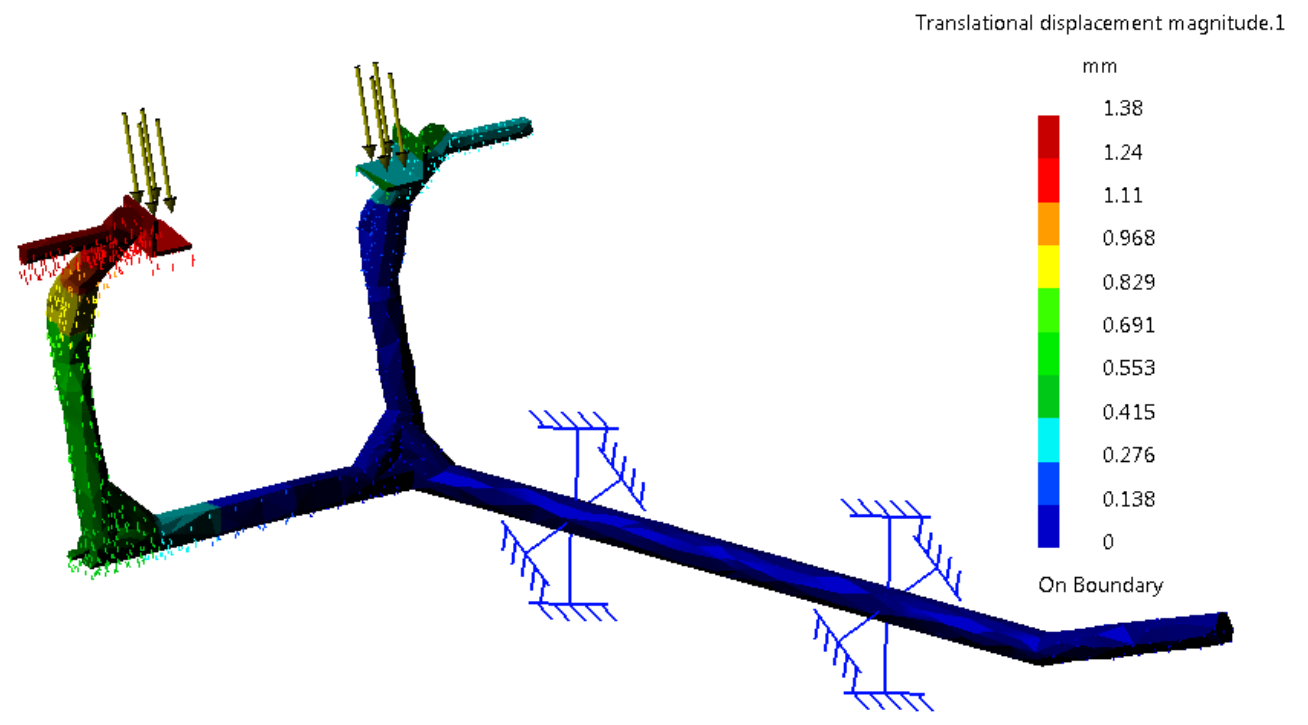

Figure 8. Translational displacement on the superbike paddock stand.

\section{PROTOTYPE FABRICATION}

A prototype of the stand was fabricated for testing with an actual superbike. The processes used in the fabrication were mainly welding and bending (Kalpakjian and Schmid, 2006), apart from finishing processes for aesthetic value. Figures 9 and 10 show the superbike paddock stand after being bent and welded together, respectively. Figure 11 shows the finished stand sprayed a metallic blue colour for aesthetics and to prevent rusting (Kalpakjian and Schmid, 2006). 


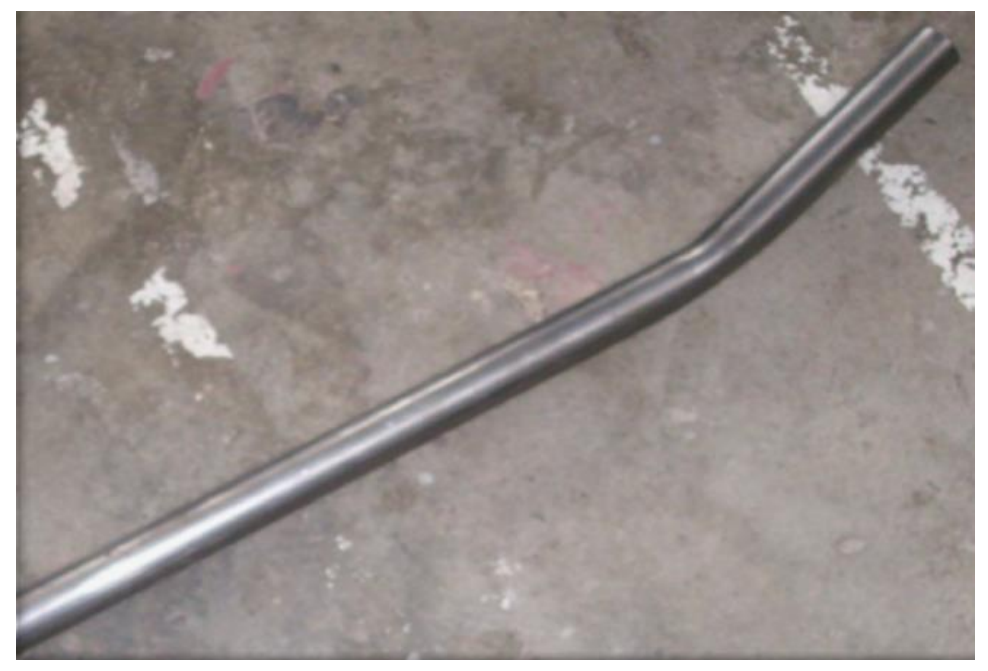

Figure 9. Handle of the superbike paddock stand after bending.

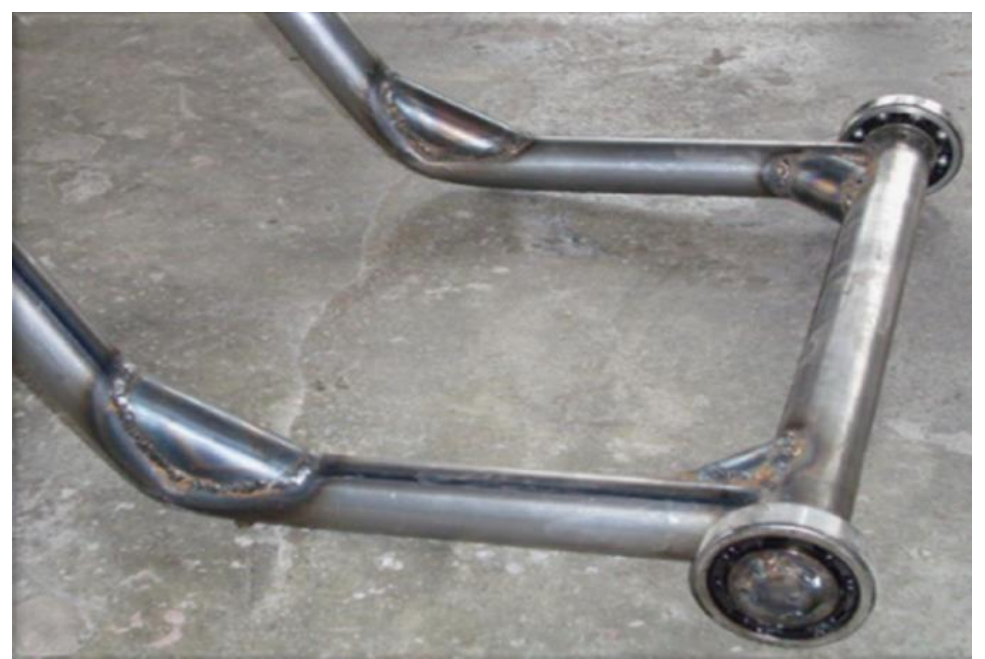

Figure 10. Frame of the superbike paddock stand after welding.

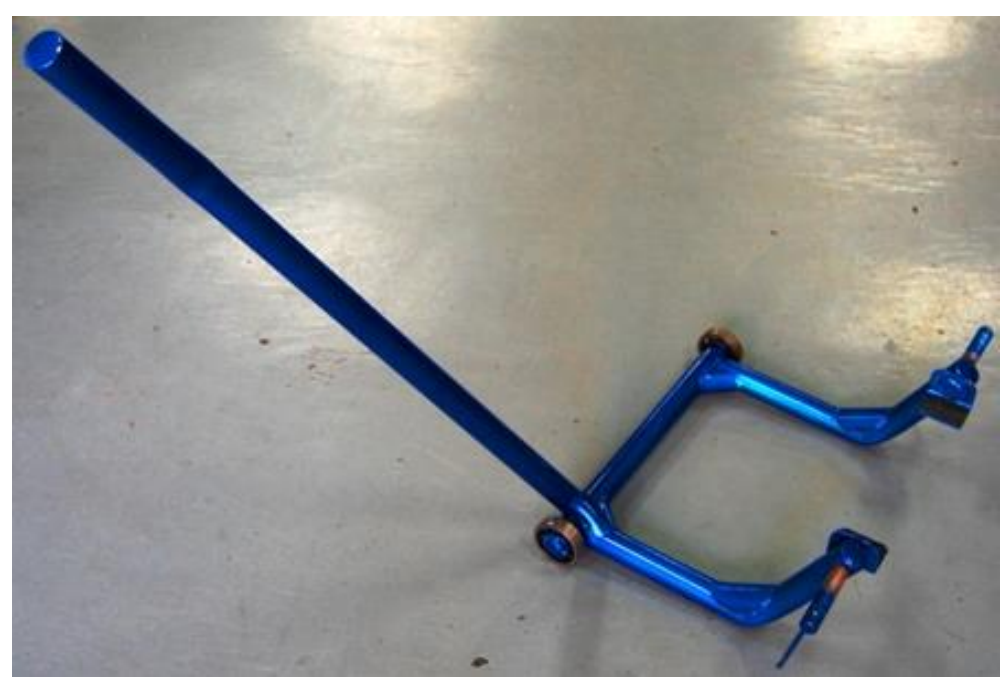

Figure 11. Frame of the superbike paddock stand after painting. 


\section{RESULTS AND DISCUSSION}

Table 2 shows the summary of the results obtained from the FEA done on the designed stand using the CATIA V5R18 software. The deformation of nearly zero shows that the paddock stand can sustain the load acting upon it. The maximum von Mises stress obtained does not exceed the maximum yield strength of mild steel; $200 \mathrm{MPa}$ (Riley et al., 1999). This verifies that the paddock stand will not fail during operation (Mingzhou et al., 2002). The small maximum translational displacement shown does not have a big impact on the structural integrity of superbike stand.

Table 2. Summary results of the finite element analysis.

\begin{tabular}{lc}
\hline \multicolumn{1}{c}{ Static Case Solution } & Results \\
\hline Deformation & Nearly zero deformation \\
Maximum Von Mises Stress & $81.2 \mathrm{MPa}$ \\
Maximum Translational Displacement & $1.38 \mathrm{~mm}$ \\
\hline
\end{tabular}

Figure 12 shows how the bike is lifted by the support on the superbike paddock stand placed under the superbike's swing arm. The support can be adjusted to various widths depending on the model of superbike, by turning the support lever on both sides of the stand. Figures 13 and 14 demonstrate how a single user operates the stand and how the stand lifts the rear tyre of the bike, allowing it to turn freely without touching the ground. For the user to lift up the superbike using this stand, the user's left hand needs to hold the superbike's left handle bar pushing it into a straight position. Then using the user's right hand, the superbike paddock stand is pushed downwards firmly until the handle of the stand touches the ground, lifting the rear tyre of the bike.

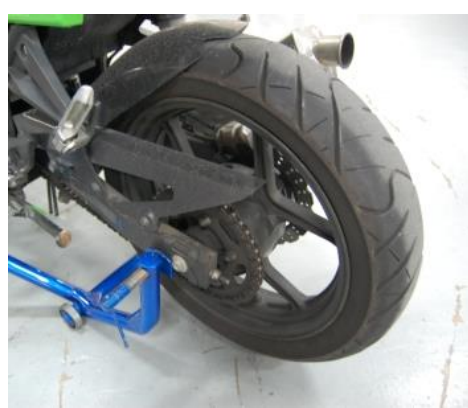

(a)

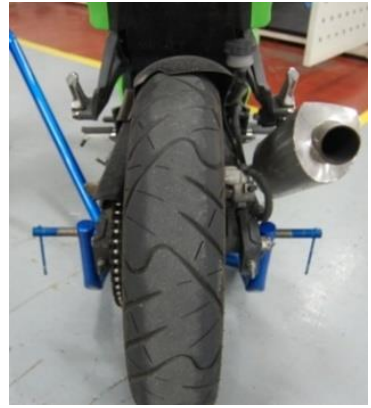

(b)

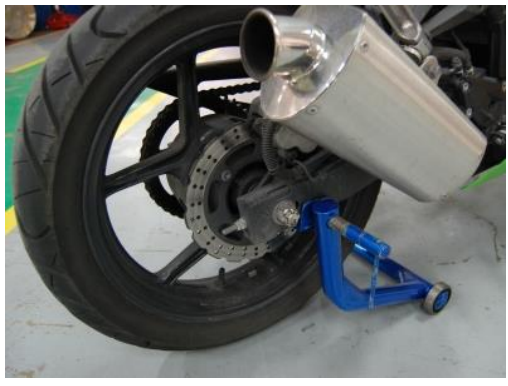

(c)

Figure 12. Position of the superbike paddock stand's support under the superbike's swing arm.

In use, the handle of the superbike paddock stand lies on the ground giving a firm and stable platform for maintenance work on the superbike (Feyen et al., 2000; Siivonen, 2005). It will not topple over because the weight of the superbike acts downwards in front of the pivot point, which is the paddock stand's wheels (Bedford and Fowler, 2008). This allows the stand to lock the superbike in a firm and stable elevated condition. Figure 15 shows several views of the superbike paddock stand elevating and holding the superbike in position. It is clear that the stand lifts the rear tyre allowing it to turn freely. 


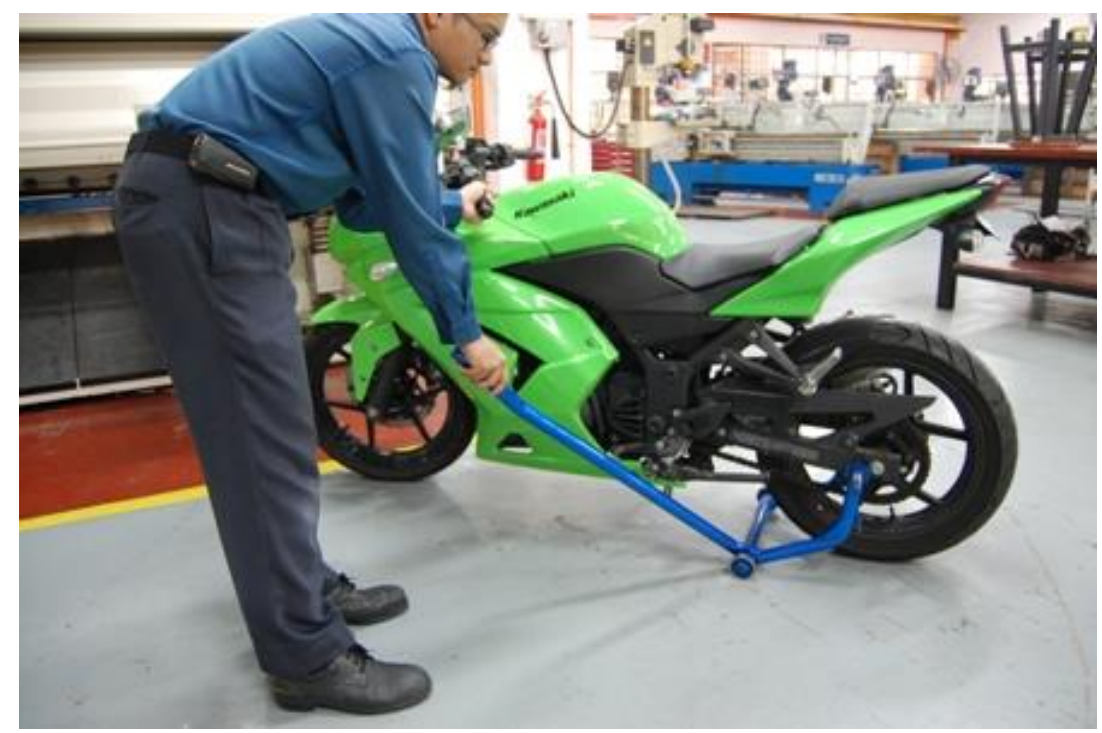

Figure 13. Single user demonstration of superbike paddock stand use.

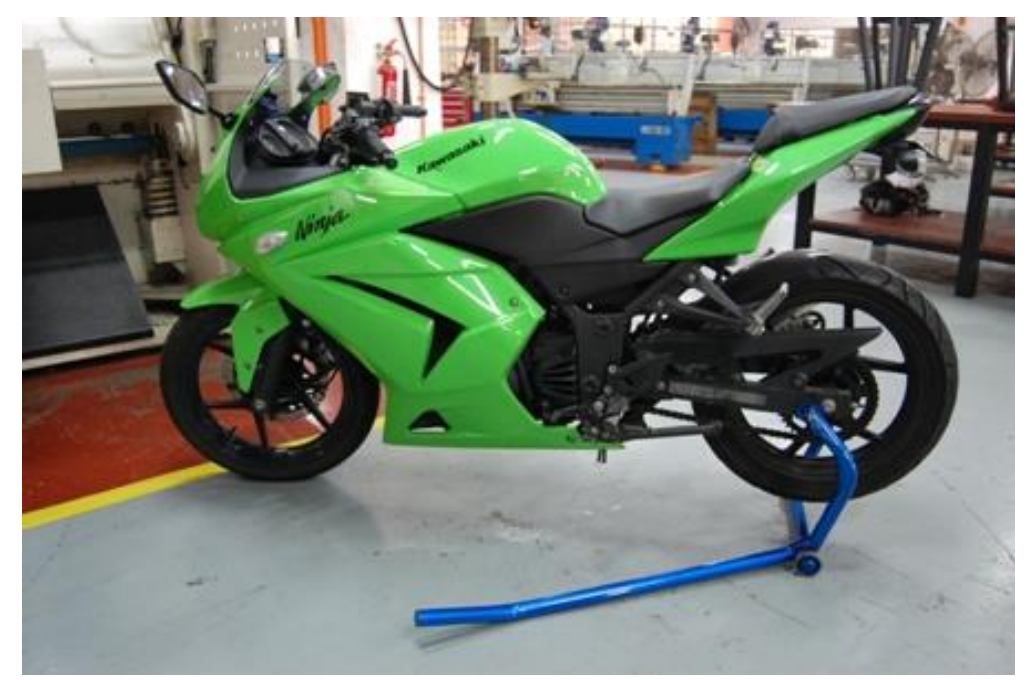

Figure 14. The superbike paddock stand with superbike's rear tyre lifted.

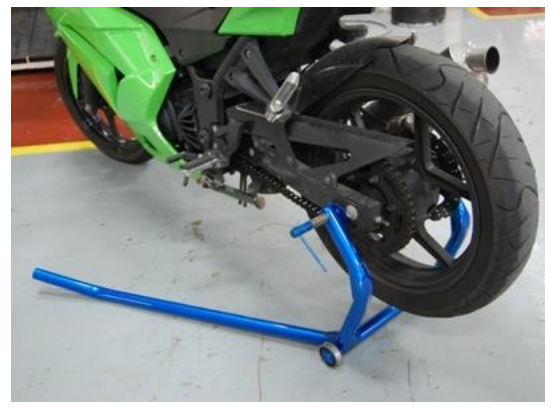

(a)

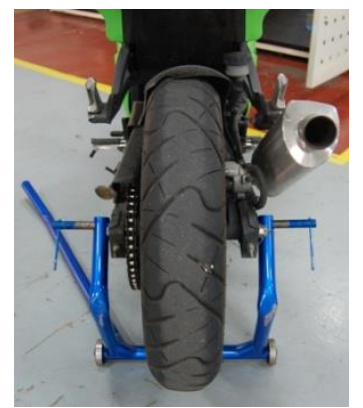

(b)

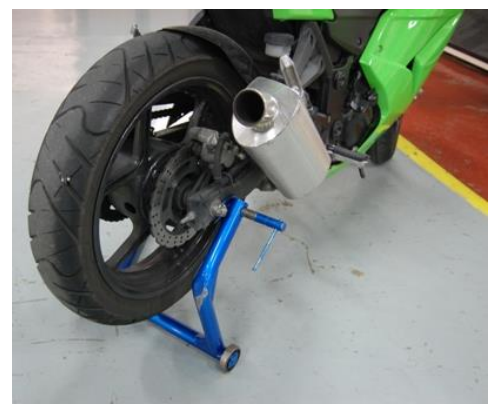

(c)

Figure 15. Different angle views of the superbike paddock stand lifting the rear tyre of the superbike. 


\section{CONCLUSIONS}

This paper outlines the results of designing a superbike paddock stand using CAD and CAE tools via CATIA V5R18 software. The designed superbike paddock stand was fabricated and tested with an actual superbike. This prototype confirmed that the designed stand is practical, convenient and easily operated by a single user.

\section{ACKNOWLEDGEMENTS}

The authors would like to acknowledge and thank all colleagues that contributed either directly or indirectly to this research work, especially the machine shop technicians, Faculty of Mechanical Engineering, Universiti Teknologi MARA Malaysia.

\section{REFERENCES}

Bedford, A. and Fowler, W. 2008. Engineering mechanics: Static. 5th Edition. New Jersey: Prentice Hall.

Budynas, R.G. and Nisbett, J.K. 2008. Shigley's mechanical engineering design. 8th Edition. Singapore: McGraw-Hill.

Feyen, R., Liu, Y., Chaffin, D., Jimmerson, G. and Josepg, B. 2000. Computer-aided ergonomics: a case study of incorporating ergonomics analyses into workplace design. Applied Ergonomics, 31(3): 291-300.

Kalpakjian, S. and Schmid, S.R. 2006. Manufacturing engineering and technology. 5th Edition. New Jersey: Prentice Hall.

Karam, F. and Kleismit, C. 2004. Using CATIA V5. Australia: Thomson.

Kuppuraju, N., Ittimakin, P. and Mistree, F. 1985. Design through selection: a method that works. Design Studies, 6(2): 91-106.

Mingzhou, S., Qiang, G. and Bing, G. 2002. Finite element analysis of steel members under cyclic loading. Finite Elements in Analysis and Design, 39 (1): 43-54.

Riley, W.F., Sturges, L.D. and Morris, D.H. 1999. Mechanics of materials. 5th Edition. USA: John Wiley \& Sons, Inc.

Siivonen, M. 2005. Motorcycle stand for maintenance, US 6840506 B2, Riihenvainiontie 4, FIN-27320 Ihode, FI.

Thakker, A., Jarvis, J., Buggy, M. and Sahed, A. 2009. 3D-CAD conceptual design of the next-generation impulse turbine using the Pugh decision-matrix. Materials \& Design, 30(7): 2676-2684.

Ulrich, K.T. and Eppinger, S.D. 2008. Product design and development. 4th Edition. New York: McGraw-Hill.

Vanvalkenburgh, C.N. 2006. Motorcycle stand, US 7000901 B1, 620 Pearl Ave., Huntsville, AL, US. 